\title{
COMMISSION 49: THE INTERPLANETARY PLASMA AND THE HELIOSPHERE LE PLASMA INTERPLANÉTAIRE ET L'HÉLIOSPHĖRE
}

President: B. Buti

Acting President: F. Verheest

Vice-President: H. Ripken

\section{INTRODUCTION}

As both the President B. Buti and the Vice-President H. Ripken were unable to attend the General Assembly, F. Verheest was appointed Acting President on proposal of the IAU General Secretary J. Bergeron.

During this General Assembly Commission 49, together with Commissions 5, 12 and 44, supported the Joint Discussion 6 on "Sun and Heliosphere: Challenges for solar-terrestrial physics, magneto- and hydrodynamics". This very successful Joint Discussion was held on August 19, all day. Papers and abstracts will be published in the Highlights in Astronomy, volume 10.

\section{BUSINESS MEETING}

The Business Meeting of Commission 49 was held on August 20, 1994 (11:00-12:30), together with Commissions 10 (Solar Activity) and 12 (Solar Radiation and Structure), prefiguring the new divisional grouping of the IAU, as approved afterwards at the Closing Session of the General Assembly. This divisional grouping emerged after many discussions during the last years between the IAU Executive Committee and Commission Presidents, because it turned out that there was considerable opposition at the grass-roots level to concerted mergers of related Commissions. Instead, related Commissions are grouped in Divisions without individual members, and Commissions 10,12 and 49 thus constitute the second Division "Sun and Heliosphere", out of 11 Divisions. Details about the intervening discussions can be read in the joint Report of the Commissions 10 and 12 in these Transactions.

At the joint Business Meeting of August 20, 1995 it turned out that only a few members identified themselves as involved with Commission 49. Coupled to the involuntary absences of both the President and the Vice-President, there were statutory questions concerning the new officers to be proposed for Commission 49. The matter was later resolved, after consultation between the IAU General Secretary, the Vice-President (reached by telephone and fax) and the Acting President. Attempts to communicate with the President proved unfortunately unsuccessful.

For the next triennium the proposal to the IAU Executive Committee was that H. Ripken advance to President, as customary, and F. Verheest be nominated as Vice-President. The Organizing Committee was to be finalized later, with composition to be found in the membership list of Commission 49.

The incoming President and Vice-President will once again try to get more and more interested members of Commission 49 to attend the next General Assembly, since also at previous Business Meetings it was noted that for various reasons the attendance was poor. 
The Working Group on Plasma Astrophysics, which had existed during the triennium 19881991 and successfully surveyed the field, was revived for the coming three years under the direction of F. Verheest, as the new Divisional umbrella could give the impression of restricting the plasma astrophysics in which Commission 49 members are interested to only that of the Heliosphere. A Working Group on Plasma Astrophysics would involve plasma astrophysicists working in other areas and not belonging to Commission 49 at present. To render some of this more explicit, the Working Group might look into whether there was a need for a name change of Commission 49, to be proposed then at the next General Assembly.

Finally, A.O. Benz was admitted as a new member of Commission 49, and G.S. Lakhina as consultant. More details concerning the joint Business Meeting can be found in the joint Report of Commissions 10 and 12 in these Transactions.

\section{FURTHER DEVELOPMENTS}

Commissions 10 and 12 held a second Business Meeting on August 23, 1994, at which the Acting President of Commission 49 was present, in view of the constitution of the board for the new Division 2: Sun and Heliosphere. Following the recommendations of the IAU Executive Committee, the divisional board will consist of the Presidents and Vice-Presidents of Commissions 10, 12 and 49 for the triennium 1994-1997. It was agreed that O. Engvold, incoming President of Commission 10, would act as Chairman of the new Division and represent it in interactions with the IAU Executive Committee. 